\title{
Loss of Heterozygosity
}

National Cancer Institute

\section{Source}

National Cancer Institute. Loss of Heterozygosity. NCI Thesaurus. Code C18016.

A genetic variation where gain, loss, or exchang e of DNA results in monoallelic loss of function mutations in a diploid cell. In the context of tumor suppressor genes, where a single copy is sufficient for functionality, loss of function for the second allele is associated with tumorigenesis. 